\title{
KINERJA KAPORIT TERHADAP PENURUNAN E-COLI PADA HIPPAM TIRTA SEJATI DI DESA KARANGREJO KECAMATAN MANYAR KABUPATEN GRESIK
}

\author{
Puji Rahayu**) dan Sugito*)
}

\begin{abstract}
Abstrak
Pembangunan sarana air bersih bertujuan agar masyarakat mendapatkan air yang memenuhi syarat kesehatan, baik bagi masyarakat yang tinggal di pedesaan maupun perkotaan. Bila air tidak memenuhi syarat kesehatan seperti yang tercantum dalam Peraturan Menteri Kesehatan RI No.416/MENKES/Per/IX/1990 tentang syarat syarat dan pengawasan kualitas air bersih ,maka air dapat menimbulkan berbagai macam gangguan baik langsung maupun tidak langsung. Penelitian ini bertujuan untuk mengetahui apakah kualitas air HIPPAM TIRTA SEJATI setelah dilakukan disinfeksi memenuhi syarat kesehatan berdasarkan Permenkes No. 416 MENKES/PER/1990 terutama untuk parameter E.Coli. Penelitian dilakukan dengan 3 (tiga) kali percobaan yaitu dengan membubuhkan kaporit dengan konsentrasi 350 ppm, 450 ppm dan 550 ppm pada bak klorinator berkapasitas 250 liter dengan harapan sisa klor pada pipa distribusi 0,2 $\mathrm{mg} / \mathrm{L}-0,5 \mathrm{mg} / \mathrm{L}$. Pemberian dosis kaporit dengan konsentrasi $450 \mathrm{ppm}$ pada Instalasi IPA HIPPAM Tirta Sejati desa Karangrejo Kecamatan Manyar Kabupaten Gresik mampu menurunkan E.Coli sampai batas memenuhi baku mutu sesuai dengan PERMENKES Nomor : 416/MENKES/Per/IX/1990. Semakin jauh jarak Instalasi makin besar angka E.Coli.Penggunaan kaporit pada dosis 350 ppm, 450 ppm dan 550 ppm dari masing-masing variasi seluruhnya menunjukkan angka sisa klor masih relatif memenuhi syarat sesuai dengan batas maksimum yang diperbolehkan.
\end{abstract}

Kata Kunci : E.Coli, HIPPAM, Kinerja, Kaporit, Penurunan.

\section{PENDAHULUAN}

Penyediaan air bersih merupakan integral dari Program Pembangunan Nasional di bidang kesehatan masyarakat. Pembangunan sarana air bersih bertujuan agar masyarakat mendapatkan air yang memenuhi syarat kesehatan, baik bagi masyarakat yang tinggal dipedesaan maupun perkotaan. Bila air tidak memenuhi syarat kesehatan seperti yang tercantum dalam Peraturan Menteri Kesehatan RI No.416/MENKES/Per/IX/1990 tentang syarat syarat dan pengawasan kualitas air bersih ,maka air dapat menimbulkan berbagai macam gangguan baik langsung maupun tidak langsung. Secara langsung air memegang peranan penting dalam penyebaran berbagai macam penyakit antara lain penyakit muntaber (muntah dan berak) atau diare, yang mana diare ini disebabkan karena bakteri E-coli yang berada dalam air bersih melebihi ambang batas.

Dampak yang disebabkan oleh air yang tidak memenuhi syarat akan terjadi penyakit. Penyakit yang disebabkan oleh karena adanya kontak dengan air diantaranya adalah typus, paratypus, disentri, (amoeba / basiler), gastroenteritis ( diare), infectus hepatitis, schistosomiasis, dan kolera. Kasus penyakit akibat diare didesa Karangrejo Kecamatan Manyar Kabupaten Gresik masuk dalam urutan 10 jenis penyakit terbanyak berdasarkan hasil laporan bulanan di poskesdes dalam 3 ( tiga ) bulan terakhir tercatat 13 kasus diare. Apabila hal ini dibiarkan maka akan berdampak lebih parah lagi seperti pada ekonomi keluarga ( pengeluaran bertambah karena untuk biaya berobat), anak tidak bersekolah, orangtua tidak bekerja karena merawat anaknya yang sakit, dsb.

Seperti kita ketahui bersama bahwa sebagian besar penduduk Indonesia berada di pedesaan dan pada umumnya mereka belum mendapatkan air yang memenuhi syarat kesehatan. Himpunan Penduduk Pemakai Air Minum ( HIPPAM ) Tirta Sejati di desa Karangrejo Kecamatan Manyar Kabupaten Gresik telah beroperasi pada awal tahun 2013sebagai bahan baku digunakan air permukaan yaitu Sungai Bengawan Solo, Instalasi Pengolahan Air (IPA) HIPPAM merupakan bantuan dari

\footnotetext{
**) Mahasiswa Teknik Lingkungan

*) Dosen Teknik Lingkungan Universitas PGRI Adi Buana Surabaya
} 
Dinas PU dan CIPTA KARYA Kabupaten Gresik Tahun Anggaran 2012.Berdasarkan hasil pemeriksaan air yang dilakukan oleh Dinas kesehatan selaku pemantau / pengawasan kualitas air bersih bahwa HIPPAM TIRTA SEJATI di desa Karangrejo Kecamatan Manyar Kabupaten Gresik kualitas air untuk parameter mikrobiologi masih diatas ambang batas syarat air bersih. Dari laporan hasil uji bakteriologis yang dilaksanakan pada tanggal 16 April 2013 menunjukkkan angka $34 \mathrm{sel} / 100 \mathrm{ml}$ sampel di reservoir, titik terdekat dari reservoir 89 sel/100 ml sampel, di titik tengah $19 \mathrm{sel} / 100$ $\mathrm{ml}$ sampel, dan titik terjauh $29 \mathrm{sel} / 100 \mathrm{ml}$ sampel sedangkan batas maksimum yang diperbolehkan adalah $10 \mathrm{sel} / 100 \mathrm{ml}$ sampel untuk perpipaan. Karena suplai air bersih didesa Karangrejo berasal dari air permukaan sehingga kecenderungan terkontaminasi oleh bakteri sangat tinggi. Maka untuk meningkatkan kualitas airnya perlu dilakukan pembenahan proses desinfeksi yang bertujuan untuk membunuh bakteri pathogen dalam air sehingga diperoleh air yang sehat. Berdasarkan data tersebut maka air bersih produksi HIPPAM ini belum memenuhi syarat sesuai PERMENKES.

Untuk mengatasi masalah tersebut maka perlu dilakukan perbaikan sistem klorinasi dengan membuat bak klorinator tambahan di Resevoir. Untuk membuat bak klorinator yang sederhana tetapi sangat berarti dengan dana yang minim didapatkan hasil yang maksimal. Bak tersebut dibuat dari tandon plastik tebal berkapasitas 250 liter yang sudah tersedia dipasaran kemudian dirancang kusus sesuai dosis kaporit yang dibutuhkan serta dosering pump yang dapat diatur. Oleh karena itu peneliti tertarik melalui penelitian dengan judul " Pengaruh Jarak Instalasi Terhadap Penurunan E-Coli Oleh Kinerja Kaporit Pada Hippam Tirta Sejati Di Desa Karangrejo Kecamatan Manyar Kabupaten Gresik."

\section{Batasan dan Ruang Lingkup}

Ruang lingkup dalam penelitian ini adalah sebagai berikut

- Penelitian dilakukan pada IPA HIPPAM Tirta Sejati di desa Karangrejo Kecamatan Manyar Kabupaten Gresik.

- Air baku Instalasi dalam penelitian ini adalah air sungai Bengawan Solo.

- Kualitas air HIPPAM yang diukur Parameter Mikrobiologi khususnya E.Coli.

\section{Perumusan Masalah}

Permasalahan dalam penelitian ini adalah sebagai berikut

- Bagaimanakah pengaruh jarak Instalasi terhadap penurunan E.Coli oleh kinerja kaporit pada IPA HIPPAM Tirta Sejati desa Karangrejo?

- Apakah kualitas air HIPPAM TIRTA SEJATI setelah dilakukan disinfeksi memenuhi syarat kesehatan berdasarkan Permenkes No.416/MENKES/PER/1990 terutama untuk parameter E-Coli.

\section{Tujuan dan Manfaat Penelitian}

Tujuan Penelitian yang akan dicapai dalam penulisan tugas akhir ini adalah:

- Untuk mengkaji pengaruh jarak Instalasi terhadap penurunan E.Colioleh kinerja kaporit pada air olahan dari HIPPAM apakah sudah memenuhi syarat sesuai dengan Permenkes.

- Untuk mengetahui Apakah kualitas air HIPPAM TIRTA SEJATI setelah dilakukan disinfeksi memenuhi syarat kesehatan berdasarkan Permenkes No.416/MENKES/PER/1990 terutama untuk parameter E-Coli.

\section{Manfaat Penelitian}

Manfaat penelitian yang ingin dicapai dalam adalah :

- Diperoleh penurunan E.Coli oleh kinerja kaporit untuk mengolah air baku pada HIPPAM.

- Masyarakat memperoleh air yang memenuhi persyaratan air bersih sesuai ketentuan yang berlaku.

- Meningkatkan derajat kesehatan sehingga masyarakat terhindar dari penyakit yang disebabkan oleh bakteri EColi.

\section{METODE PENELITIAN}

Kegiatan penelitian ini merupakan kegiatan pemeriksaan atau penyelidikan pada suatu obyek tertentu untuk mencari kebenaran pada suatu tujuan pembahasan.Dalam metode penelitian dibahas langkah demi langkah agar penelitian terarah dan tepat sasaran.Pokok pokok bahasan dalam bab ini adalah sebagai berikut.

\section{Rancangan Penelitian.}

Sesuai dengan judul penelitian Pengaruh jarak Instalasi terhadap penurunan E-Coli oleh kinerja Kaporit pada Hippam Tirta Sejati di desa Karangrejo Kecamatan Manyar Kabupaten Gresik maka rancangan penelitian dilakukan dengan (3) tiga kali 
Puji Rahayu \& Sugito : Kinerja Kaporit Terhadap Penurunan E-Coli Pada HIPPAM Tirta Sejati Di Desa Karangrejo Kecamatan Manyar Kabupaten Gresik

percobaan yaitu dengan membubuhkan kaporit dengan konsentrasi $350 \mathrm{ppm}$, 450ppm dan $550 \mathrm{ppm}$ pada bak klorinator berkapasitas 250 liter dengan harapan sisa klor pada pipa distribusi $0,2 \mathrm{mg} / \mathrm{tt}-0,5$ $\mathrm{mg} / \mathrm{lt}$.Desain penelitian merupakan tahapan proses yang diperlukan dalam merencanakan dan melakukan penelitian. Seperti pada gambar1.

Adapun kerangka penelitian dalam tugas akhir ini dapat dilihat pada gambar 1

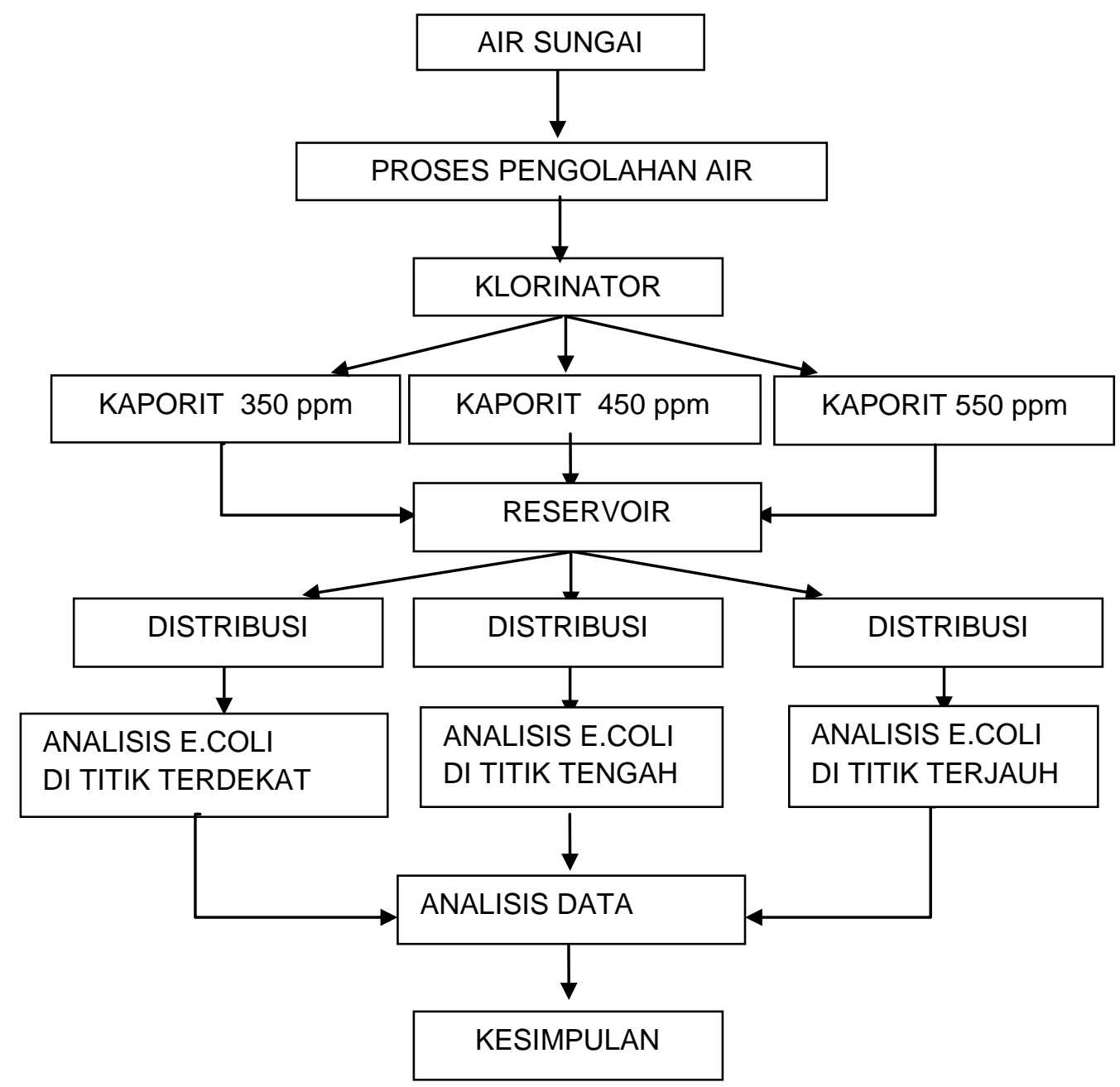

Gambar 1. Kerangka Penelitian

Populasi dalam penelitian ini adalah air baku badan air sungai Bengawan Solo di desa Karangrejo Kecamatan Manyar yang merupakansalah satu sungai terbesar di Kabupaten Gresik. Sedangkan yang menjadi sampel dalam penelitian ini adalah air olahan dari IPA HIPPAM Tirta Sejati. Alat dan bahan yang digunakan antara lain : Stopwatch, meteran,gunting,tandon plastik tebal 250 liter,selotip,dossing pump,pipa lentur. Alat dan bahan untuk menguji bakteri E.Coli yang digunakan timbangan,botol steril,pinset,kapas,korek api,spiritus,lampu embusen,tas tempat sampel,alat pencatat dan label,air dan kaporit. Alat dan bahan untuk menguji sisa klor yang digunakan antara lain Alat Photometri kit, Air olahan IPA HIPPAM, DPD 1 (Dietil Penilendiamin)

Langkah Langkah Penelitian

Tahap 1 Penelitian percobaan

- Membuat larutan kaporit 350 ppm pada bak klorinator.

- Mengisi klorinator dengan larutan kaporit.

- Mengalirkan kaporit kedalam air setelah melewati proses pengolahan pada bak Reservoir.

- Mengambil sampel air bersih pada titik terdekat dari reservoir, titik tengah dan 
titik terjauh pada jaringan sitem distribusi penduduk untuk dilakukan analisa E.Coli dan sisa klor.

- Mengulangi langkah 1 s/d 4 dengan menggunakan kaporit dengan dosis 450 ppm dan 550 ppm.

- Analisa E. Coli dengan parameter Total Bakteri Koliform.(MPN).

- Analisa sisa klor dengan Photometri.

- Tabulasi data hasil analisa laboratorium.

Tahap 2 Teknik Pembubuhan kaporit

- Pembubuhan kaporit 350 ppm pada klorinator

- Pada hari berikutnya pembubuhan kaporit 450 ppm

- Mengulangi langkah no 2 dengan pembubuhan dosis kaporit 550 ppm pada klorinator

Variabel penelitian

- Variabel

Menurut Sutrisno Hadi (1991) yang menyatakan bahwa : "Variabel adalah gejala yang bervariasi dan menjadi obyek penelitian"

Dalam penelitian ini ada 2 (dua) variabel yaitu :

- Variabel bebas (Indenpenden variabel) yaitu variabel yang mempengaruhi variabel terikat dalam penelitian ini adalah pemberian dosis kaporit. Dalam penelitian variasi dosis kaporit yang digunakan adalah 350 ppm, 450 ppm dan 550 ppm.

- Variabel terikat (Dependen variabel) yaitu variabel yang terjadi karena pengaruh variabel bebas dalam penelitian ini adalah kualitas air bersih ditinjau dari aspek biologis E.coli.

\section{Waktu dan Tempat Penelitian}

Penelitian dilakukan pada bulan Oktober 2013 s/d Januari 2014 sedangkan tempat penelitian dilakukan di Instalasi Pengolahan Air Bersih HIPPAM Tirta Sejati desa Karangrejo Kecamatan Manyar Kabupaten Gresik.

\section{Metode Pengumpulan Data}

Data yang dikumpulkan dalam identifikasi kinerja Instalasi Pengolahan Air Bersih HIPPAM Tirta Sejati adalah data yang didapatkan langsung melalui analisa dan pengukuran di lapangan,meliputi data kualitas air baku dan air olahan setelah melalui proses pengolahan. Data ini diperoleh dari UPT Laboratorium Kesehatan Daerah Dinas Kesehatan Kabupaten Gresik.
Adapun Teknik Pengumpulan Data dalam penelitian ini adalah :

- Teknik Pengambilan SampelPopulasi Sampel

Populasi air olahan IPA HIPPAM dalam sampel ini adalah :

Sampel air yang diuji E.Coli masing masing pada dosis kaporit 350 ppm, 450ppm dan 550 ppm setelah air terolah pada IPA HIPPAM dan pada sistemjaringan distribusi diharapkan sisa klor $0,2 \mathrm{mg} / \mathrm{lt}-0,5 \mathrm{mg} / \mathrm{lt}$.Sampel air bersih dalam penelitian ini diambil dengan 3 (tiga ) kali percobaan.

- Dimulai dari dosis kaporit 350 ppm diambil pada titik terdekat, titik tengahdan terjauh pada jaringan distribusi kemudian dianalisa bakteri E.Coli dan sisa klor

- Sampel diambil lagi dengan dosis kaporit 450 ppm pada titik terdekat, titik tengah dan titik terjauh pada jaringan distribusi kemudian dianalisa bakteri E.coli dan sisa klor.

- Kemudian sampel diambil lagi pada dosis kaporit 550 ppm pada titik terdekat, titik tengah dan terjauh pada jaringan distribusi dan dianalisa E.coli dan sisa klor.

Menurut Andrew D.Eaton.et.all, Analisis E.Coli dengan menggunakan Metode Tabung Ganda Formula Thomas

Standart operasional pelayanan Pemeriksaan bakteri golongan koliform pada air

METODE : Tabung Ganda

PRINSIP : Bakteri yang berbentuk batang, bersifat aerob atauFakultatif aerob, tidak membentuk spora, bersifat gram negatif dan dapat meragikan laktosa serta membentuk gas dalam waktu $2 \times 24$ jam pada suhu $35^{\circ} \mathrm{C} / 37^{\circ} \mathrm{C}$.

\section{Alat yang Dipakai}

Alat Laboratorium : Autoclave, incubator $35^{\circ} \mathrm{C} / 37^{\circ} \mathrm{C}$, Timbangan, kompor listrik, lampu spiritus, dan rak tabung.

Alat Gelas : pipet, tabung reaksi, tabung durham, ose.

Media yang digunakan :Lactose Broth (LB),Air Pengencer (Buffer Phosphat),Brilliant Green bile Lactose Broth (BGLB) $2 \%$.

METODE 15 TABUNG : digunakan untuk semua sampel air seperti air yang belum diolah berasal dari air baku, air minum, air bersih.

UJI PRADUGA (PRESUMTIF TEST)

Siapkan 5 tabung LB2 ( Lactose Broth doubel Strength ) isi @ 5 ml dan 10 tabubg 
Puji Rahayu \& Sugito : Kinerja Kaporit Terhadap Penurunan E-Coli Pada HIPPAM Tirta Sejati Di Desa Karangrejo Kecamatan Manyar Kabupaten Gresik

LB 1( Lactose Broth doubel Strength ) isi 10 @ ml.

Contoh uji dikocok sampai Homogen.

Inokulasikan ke dalam 5 tabung LB2 masing masing $10 \mathrm{ml}$ contoh, ke dalam 5 tabung
LB1 inokulasikan $1 \mathrm{ml}$ contoh dan 5 tabung lainnya inokulasikan $0,1 \mathrm{ml}$ contoh.

Semua tabung LB1 diinkubasi pada suhu $37^{\circ} \mathrm{C}$ selama 48 hari.

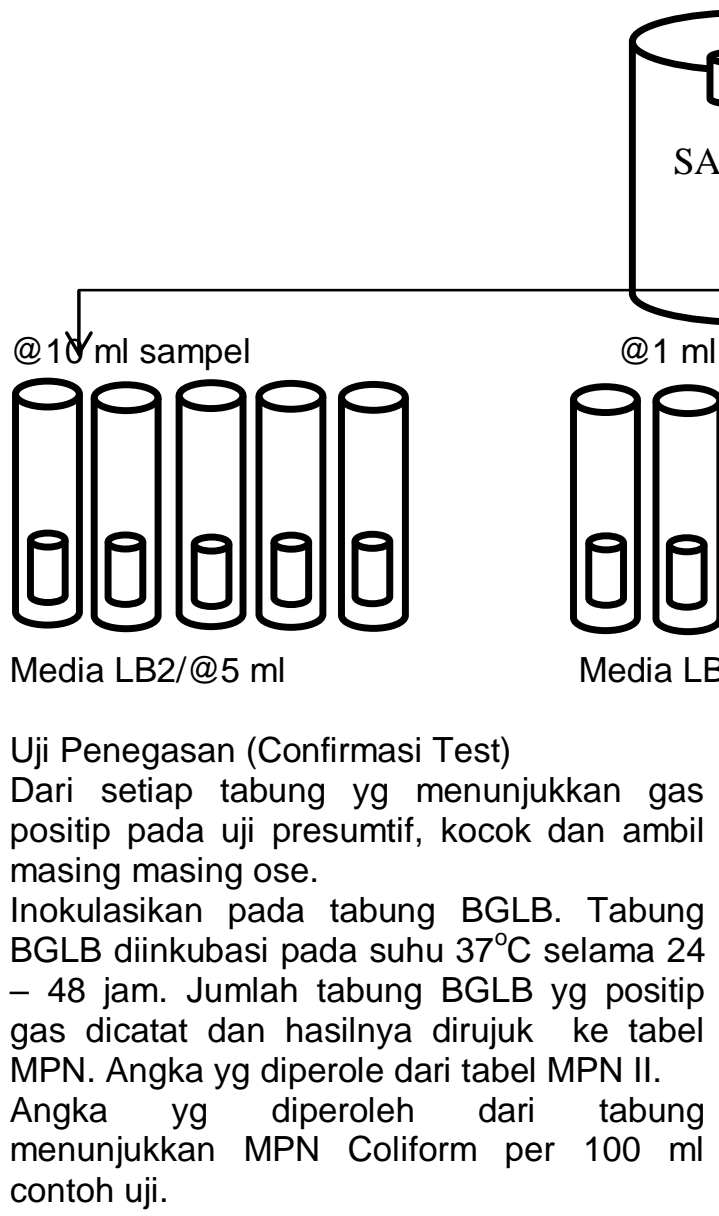

@0,1 ml satmpel

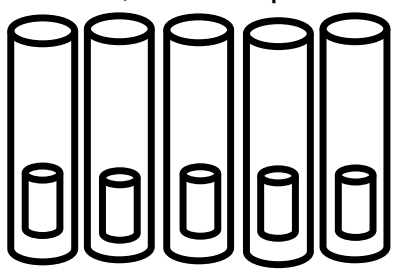

Media LB1/@10 ml
Uji Penegasan (Confirmasi Test)

Dari setiap tabung yg menunjukkan gas positip pada uji presumtif, kocok dan ambil masing masing ose.

Inokulasikan pada tabung BGLB. Tabung BGLB diinkubasi pada suhu $37^{\circ} \mathrm{C}$ selama 24 - 48 jam. Jumlah tabung BGLB yg positip gas dicatat dan hasilnya dirujuk ke tabel MPN. Angka yg diperole dari tabel MPN II. menunjukkan MPN Coliform per $100 \mathrm{ml}$ contoh uji.

\section{HASIL PENELITIAN}

$\begin{array}{ll}\text { Data yang diperoleh dari hasil } \\ \text { penelitian } & \text { dilapangan }\end{array}$ langsung.Penelitian ini dilakukan pada HIPPAM Tirta Sejati desa Karangrejo dan dianalisa di UPT Laboratorium Kesehatan Daerah Kabupaten Gresik. Data yang sudah berhasil dikumpulkan melalui kegiatan penelitian ini adalah hasil Uji Laboratorium parameter E-Coli untuk air sebelum dilakukan penambahan kaporit seperti pada tabel

Tabel 1. Hasil uji Bakteriologis sebelum penelitian

\begin{tabular}{|c|c|c|c|c|c|}
\hline $\begin{array}{l}\text { Dosis } \\
\text { (ppm) }\end{array}$ & kaporit & $\begin{array}{l}\text { Titik } 1 \text { terdekat } \\
{ }^{*} \text { ( di Reservoar ) }\end{array}$ & $\begin{array}{l}\text { Titik } 2 \text { tengah } \\
{ }^{*}( \pm 500 \mathrm{~m})\end{array}$ & $\begin{array}{l}\text { Titik } 3 \text { tengah } \\
{ }^{*}( \pm 600 \mathrm{~m})\end{array}$ & $\begin{array}{l}\text { Titik } 4 \text { terjauh } \\
{ }^{*}( \pm 2000 \mathrm{~m})\end{array}$ \\
\hline 300 & & 34 & 19 & 29 & 89 \\
\hline
\end{tabular}

*Jarak dari IPA HIPPAM

Data hasil penelitian setelah pemberian kaporit dengan dosis bervariasi sesuai dengan variabel adalah seperti pada tabel 2 .

Tabel 2. Hasil Penelitian setelah pemberian kaporit dengan dosis bervariasi

\begin{tabular}{llllll}
\hline \multirow{2}{*}{ Dosis kaporit $(\mathrm{ppm})$} & \multirow{2}{*}{ Titik } & \multicolumn{4}{c}{ Total bakteri koliform } \\
& Reservoar $)$ & & $1^{*}\left(\mathrm{ditik} 2^{*}( \pm 500 \mathrm{~m})\right.$ & Titik $^{*}( \pm 600 \mathrm{~m})$ & Titik $4^{*}( \pm 2000 \mathrm{~m})$ \\
\hline 350 & 28 & 6 & 26 & $\geq 1898$ \\
450 & 0 & 2 & 46 & 0 \\
550 & 38 & 14 & 37 & 6 \\
\hline
\end{tabular}

*Jarak dari IPA HIPPAM 
Puji Rahayu \& Sugito : Kinerja Kaporit Terhadap Penurunan E-Coli Pada HIPPAM Tirta Sejati Di Desa Karangrejo Kecamatan Manyar Kabupaten Gresik

Grafik kandungan E.Coli pada saluran distribusi seperti pada gambar 1 Kaporit 350 ppm

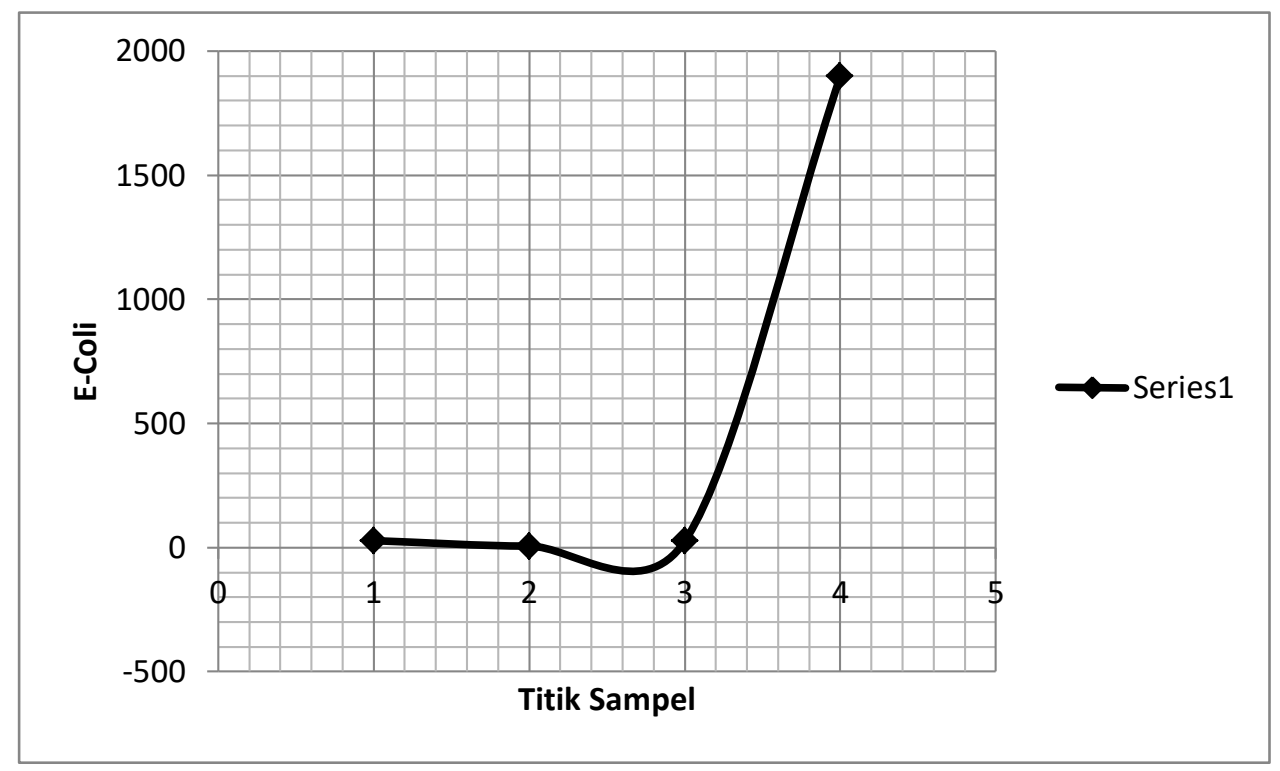

Gambar 1 Grafik kandungan E.Coli dosis kaporit 350 ppm

Berdasarkan grafik gambar 4.1 Pemberian kaporit dengan dosis $350 \mathrm{ppm}$ maka terlihat kandungan E.Coli pada jaringan distribusi menunjukkan hasil yang bervariasi hanya 1 sampel yg memenuhi syarat yaitu pada titik 2 ( titik tengah )dengan jarak $\pm 600 \mathrm{~m}$ dari Reservoir, sedangkan sampel di titik 4 pada jarak \pm 2000 m dari Reservoir menunjukkan angka kuman E .Coli $\geq 1989$ / $100 \mathrm{ml}$.

Grafik kandungan E.Coli pada saluran distribusi seperti pada gambar 2 Kaporit 450 ppm

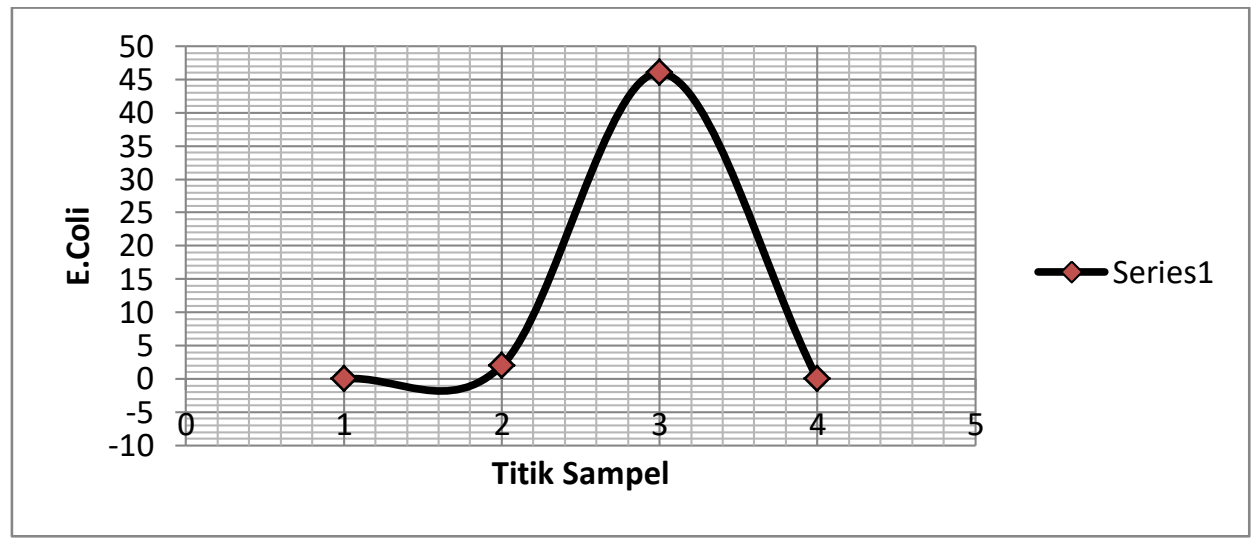

Gambar .2 Grafik kandungan E.Coli dosis kaporit 450 ppm

Berdasarkan grafik gambar 4.2 Pemberian kaporit dengan dosis $450 \mathrm{ppm}$ maka terlihat kandungan E.Coli pada jaringan distribusi menunjukkan hasil yang bervariasi dari 4 titik sampel yg diambil terdapat 3 titik sampel yg memenuhi syarat yaitu pada titik 1 (Reservoir), titik 2 (titik tengah )dengan jarak $\pm 600 \mathrm{~m}$, dan titik 4 (titik terjauh) dengan jarak $\pm 2000 \mathrm{~m}$ dari Reservoir. 
Puji Rahayu \& Sugito : Kinerja Kaporit Terhadap Penurunan E-Coli Pada HIPPAM Tirta Sejati Di Desa Karangrejo Kecamatan Manyar Kabupaten Gresik

Grafik kandungan E.Coli pada saluran distribusi seperti pada gambar 3 Kaporit 550 ppm

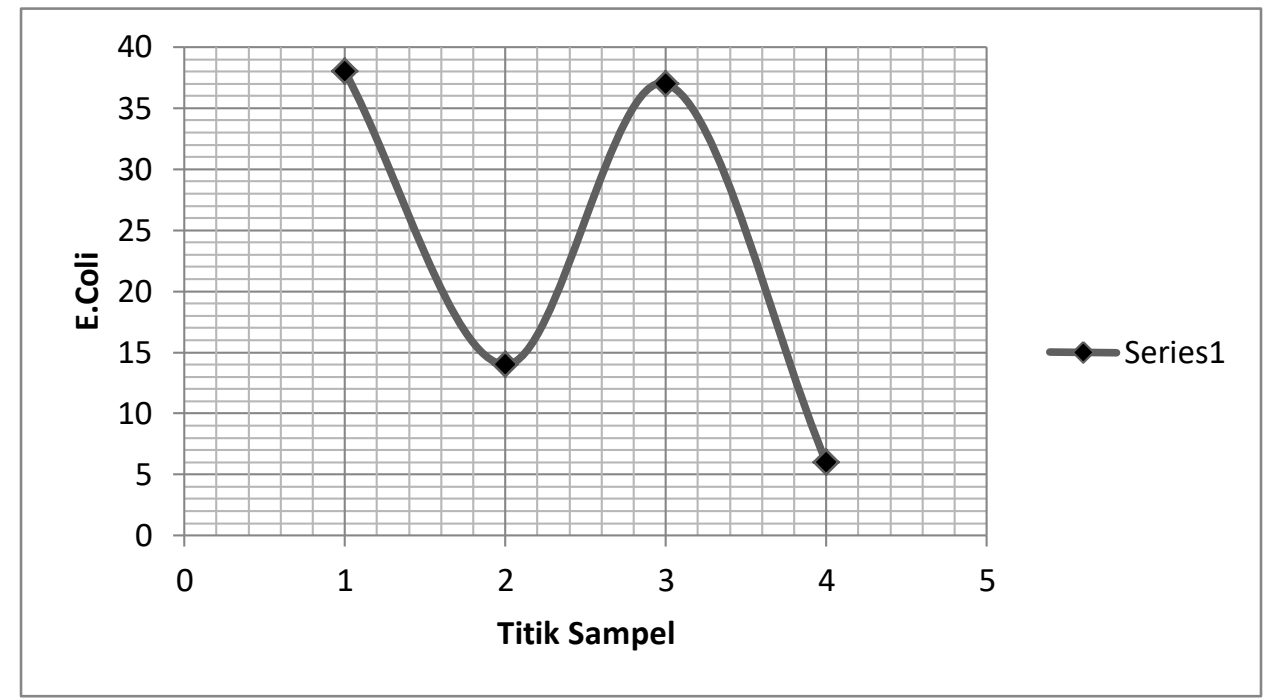

Gambar 3 Grafik kandungan E.Coli pada dosis 550 ppm.

Berdasarkan grafik gambar 4.3 Pemberian kaporit dengan dosis $550 \mathrm{ppm}$ maka terlihat kandungan E.Coli pada jaringan distribusi menunjukkan hasil yang bervariasi hanya terdapat 1 sampel yg memenuhi syarat yaitu pada titik 4 (titik terjauh)dengan jarak $\pm 2000 \mathrm{~m}$ dari Reservoir. Grafik kandungan E.Coli pada saluran distribusi seperti pada gambar 4. Kaporit 350 ppm, 450 ppm, 550 ppm.

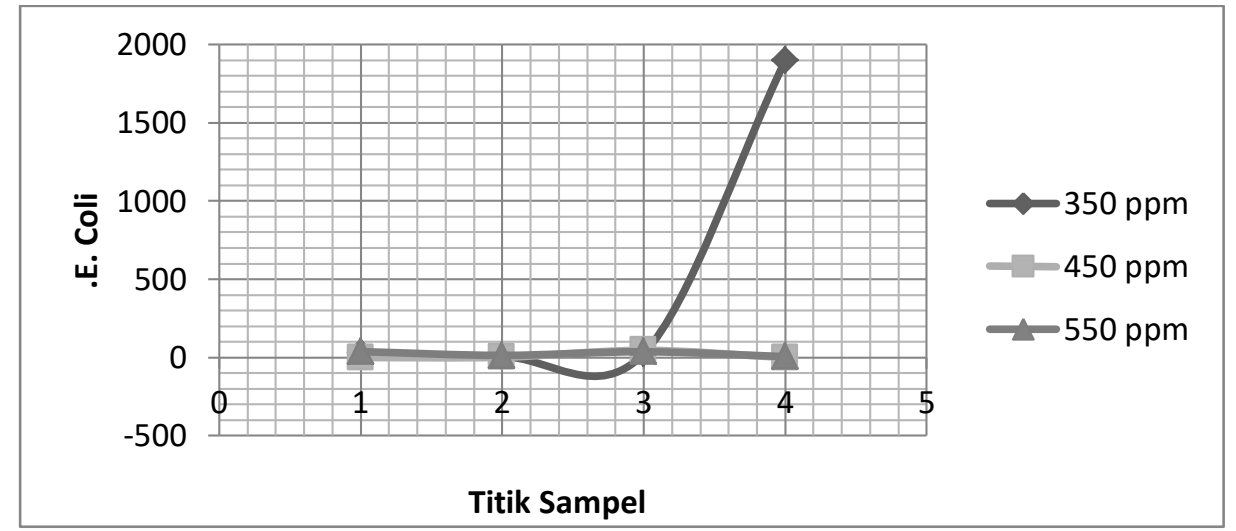

Gambar 4. Grafik kandungan E.Coli pada berbagai variabel penambahan kaporit.

Berdasarkan grafik gambar 4 Pemberian kaporit dengan dosis bervariasi $350 \mathrm{ppm}$, $450 \mathrm{ppm}$ dan $550 \mathrm{ppm}$ maka terlihat kandungan E.Coli pada jaringan distribusi menunjukkan hasil yang bervariasi sesuai dengan variabel pada tabel 4 .

Data hasil penelitian uji parameter sisa klor setelah dilakukan penambahan kaporit seperti pada tabel 4.
Tabel 4. Hasil penelitian uji parameter sisa klor

\begin{tabular}{lllll}
\hline $\begin{array}{l}\text { Dosis } \\
(\mathrm{ppm})\end{array}$ & Kaporit & \multicolumn{4}{l}{ Sisa Klor } & & \\
& Titik 1 & Titik 2 & Titik 3 & Titik 4 \\
\hline 350 & 0,31 & 0,17 & 0,16 & 0,11 \\
450 & 0,26 & 0,15 & 0,10 & 0,26 \\
550 & 0,23 & 0,28 & 0,09 & 0,5 \\
\hline
\end{tabular}

Dari tabel 4 dapat disimpulkan bahwa pada pemberian dosis kaporit 350 ppm,450 ppm dan 550 ppm angka sisa klor menunjukkan masih dalam batas maksimum yang diperbolehkan. 
Grafik sisa klor kaporit 350 ppm, 450 ppm, 550 ppm seperti Gambar 5

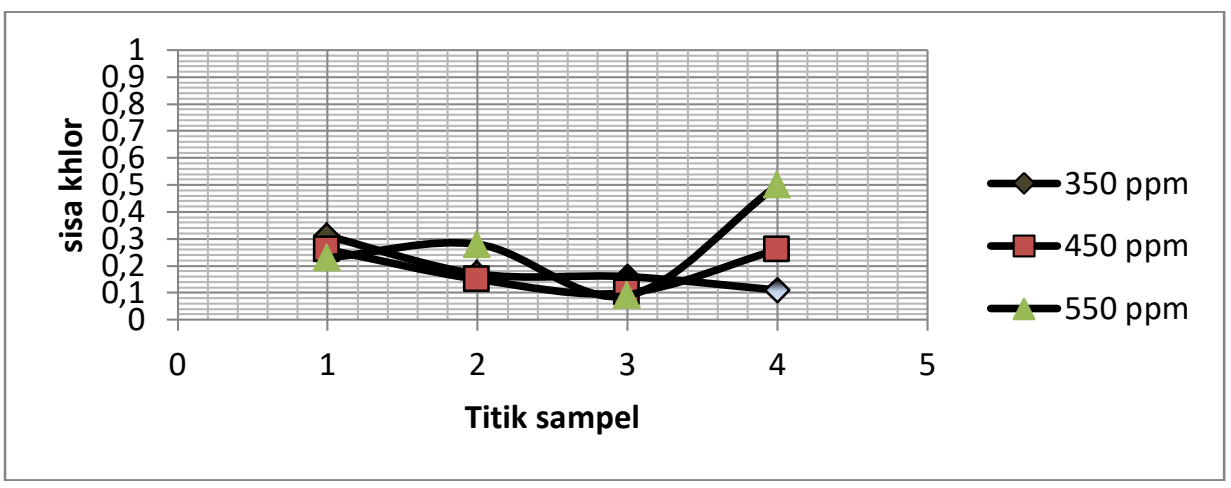

Gambar 5 Grafik sisa klor

Berdasarkan melihat tabel sisa klor dengan melihat kandungan E.Coli dan sisa klor maka penambahan dosis kaporit 350 ppm, 450 ppm dan 550 ppm menunjukkan hasil yang masih dalam batas maksimum yang diperbolehkan untuk persyaratan air bersih sistem perpipaan.

\section{PEMBAHASAN}

Berdasarkan hasil uji laboratorium air olahan IPA HIPPAM Tirta Sejati desa Karangrejo kecamatan Manyar Kabupaten Gresik sebelum penelitian dari 4 titik sampel seluruhnya menunjukkkan angka total bakteri koliform diatas NAB ( NilaiAmbang Batas ) yang ditentukan untuk perpipaan sehingga tidak memenuhi syarat menurut PERMENKES

No.416/MENKES/Per/IX/1990.

Berdasarkan tabel 2 untuk penggunaan dosis kaporit sebesar $350 \mathrm{ppm}$ keberadaan angka E.coli cenderung tidak teratur bahkan pada titik terjauh sangat tinggi, pada penggunaan dosis kaporit 450 ppm ada kecenderungan teratur dari titik 1 sampai dengan titik 3 yang mana keberadaan E.Colinya makin besar walaupun turun lagi pada titik 4 yaitu angka 0 , pada penggunaan dosis kaporit $550 \mathrm{ppm}$ data E.Coli di keempat titik tidak linier sehingga tidak bisa dipakai untuk menyimpulkan.

Menurut tabel 3 sisa klor pada penggunaan kaporit pada dosis $350 \mathrm{ppm}$, 450 ppm dan 550 ppm dari masing-masing variasi seluruhnya menunjukkan angka sisa klor masih relatif memenuhi syarat sesuai dengan batas maksimum yang diperbolehkan yaitu $0,2 \quad-\quad 0,5$
mg/lt.Mekanisme klorinasi klor dapat membunuh bakteri karena kaporit menghasilkan gas klor.

\section{KESIMPULAN DAN SARAN \\ Kesimpulan}

Berdasarkan analisa pembahasan dalam penelitian ini maka dapat ditarik kesimpulan bahwa :

- Penggunaan dosis kaporit maksimum pada treatment adalah $450 \mathrm{ppm}$ padalnstalasi IPA HIPPAM Tirta Sejati desa Karangrejo Kecamatan Manyar Kabupaten Gresik sudah memenuhi syarat sesuai dengan PERMENKES Nomor : 416/MENKES/Per/IX/1990.

- Semakin jauh jarak Instalasi makin besar angka E.Coli.

- Penggunaan kaporit pada dosis 350 ppm, $450 \mathrm{ppm}$ dan $550 \mathrm{ppm}$ dari masingmasing variasi seluruhnya menunjukkan angka sisa klor masih relatif memenuhi syarat sesuai dengan batas maksimum yang diperbolehkan yaitu $0,2-0,5 \mathrm{mg} / \mathrm{lt}$.

\section{Saran}

- Diharapkan HIPPAM Tirta Sejati desa Karangrejo Kecamatan Manyar Kabupaten Gresik secara berkala tetap melakukan uji Bakteriologis dan sisa klor setiap bulan sekali sesuai dengan Tata cara pelaksanaan pengawasan kualitas air minum pada reservoir dan jaringan pipa distribusi.

- Untuk pengembangan selanjutnya menambah jaringan pipa distribusi agar seluruh penduduk desa Karangrejo bisa terlayani. 
Puji Rahayu \& Sugito : Kinerja Kaporit Terhadap Penurunan E-Coli Pada HIPPAM Tirta Sejati Di Desa Karangrejo Kecamatan Manyar Kabupaten Gresik

\section{DAFTAR PUSTAKA}

Anonymous, 2002. ATSDR 2002 "Calcium Hypoclorite \& Sodium Hypoclorite" Division of To xicology. toxFAQS.ATSDR.ATLENTA. http//www.atsdr.cdc.gov/toxtaq.html. diunduh tanggal 12 Juni 2013

Anonymous, Disinfeksi dan Oksidasihttp://www.airlimbahku.com/2006/03/kaporit- pembasmibakteridiunduh tangal 18 juni 2013

D. Eaton, Andrew. Et all, 2005. Standart Methods for the examinition of water \& waster water.

Depkes RI, 1998. Prosedur Pelaksanaan Pemeriksaan Kualitas Air secara Bakteriologi, Dirjen PPM \& PLP. Jakarta.

Fair, M.G, Geyer, C.J, dan Okun, D.A, 1981 Water and Wastewater Engineering, John Wiley \& Sons, New York.

Hadi, Wahono .. Perencanaan bangunan pengolahan air minum.ITS.

Kuntaman, 20 Oktober 2011. Escherchia Coli, Sahabat Manusia yang Disia-siakan,Guru Besar Mikrobiologi. Kedokteran / Mikrobiologi Teknik, Fakulta Kedokteran UNAIR / RSUD dr. Soetomo Surabaya / Rumah Sakit Universitas Airlangga, diunduh tanggal 3 Juni 2013

PerMenKes RI No. 416/MENKES/Pes/IX/1990 tentang syarat-syarat dan pengawasan kualitas air bersih.

Susanto, Eko. 1998. Kajian tentag dosis optimal kaporit terhadap efektifitas penurunan angka kuman golongan Coli pada air gambut di desa Semilegi kecamatan Selakan kabupaten Sambar tahun 1998. Diunduh tanggal 12 Juni 2013 